\title{
Oviposition and subsequent depredation of Snapping Turtle (Chelydra serpentina) nests in fresh asphalt
}

\author{
Shane R. De Solla ${ }^{1, ~ *}$ and JaClyn A. Gugelyk ${ }^{1}$ \\ ${ }^{1}$ Wildlife and Landscape Science Directorate, Environment and Climate Change Canada, Canada Centre for Inland Waters, \\ Burlington, Ontario L7S 1A1 Canada \\ *Corresponding author: shane.desolla@canada.ca
}

de Solla, S.R., and J.A. Gugelyk. 2018. Oviposition and subsequent depredation of Snapping Turtle (Chelydra serpentina) nests in fresh asphalt. Canadian Field-Naturalist 132(2): 103-107. https://doi.org/10.22621/cfn.v132i2.2035

\begin{abstract}
On 28 June 2009, three Snapping Turtle (Chelydra serpentina) nests were found oviposited in fresh asphalt beside a bridge in Algonquin Provincial Park, Ontario. One nest was excavated immediately; the other two were left untouched. The two nests left in situ were revisited on 28 July when it was discovered that one nest had been depredated by an unknown predator. Evidence of the third nest was obliterated by tracks of large mammals crossing the bridge. These observations suggest that predators find turtle nests despite the strong odour of asphalt. To examine potential negative impacts of asphalt on turtle eggs, five clean Snapping Turtle eggs, collected elsewhere in Algonquin Provincial Park, were buried in asphalt on 28 July. After eight days, the translocated eggs had obvious staining and contained $0.081-0.376 \mu \mathrm{g} / \mathrm{g}$ (wet weight) polycyclic aromatic hydrocarbons (PAHs), presumably resulting from asphalt exposure. The risk of exposure to PAHs or other chemicals associated with asphalt is unknown, but the levels of PAHs in these eggs appeared lower than those associated with acute toxicity.
\end{abstract}

Key words: Snapping Turtle; Chelydra serpentina; asphalt; polycyclic aromatic hydrocarbons; oviposition; predation; Algonquin Provincial Park; Ontario

\section{Introduction}

In landscapes with substantial human activity, Snapping Turtles (Chelydra serpentina) and other freshwater turtle species oviposit in a variety of artificial substrates, such as dams, railway and road embankments, roadsides, vegetable gardens, compost, coal ash, and sand or gravel pits (Loncke and Obbard 1977; de Solla et al. 2001; Nagle et al. 2001; de Solla and Fernie 2004; Aresco 2005). In many parts of their range, most female Snapping Turtles nest in artificial substrates, because natural areas might not be available, and turtles may travel considerable distances to nest on embankments or dams (Obbard and Brooks 1980).

The use of artificial or anthropogenically modified substrates by turtles can have consequences for the developing embryo (e.g., Nagle et al. 2001; de Solla and Martin 2007), and possibly for egg predators and the nesting female turtles. Here we report oviposition by three Snapping Turtles in asphalt, depredation of one of those nests by an unknown predator, and the absorption of polycyclic aromatic hydrocarbons (PAHs) in turtle eggs.

\section{Methods}

\section{Field-site observations}

A search was conducted for Snapping Turtle nests in Algonquin Provincial Park, Ontario, to collect eggs for a toxicological study (internal Animal Care protocol 0902 by Environment Canada) examining their absorption of polycyclic aromatic hydrocarbons (PAHs). Al- gonquin Provincial Park has previously been used as a source of eggs for experiments to examine toxicity of soil-borne contaminants (e.g., de Solla and Martin 2007). Roadsides were searched for turtle nests, which were excavated and the eggs removed.

During the afternoon of 28 June 2009 on the road along Costello Creek south of Lake Opeongo (45.61 $6815^{\circ} \mathrm{N}, 78.344354^{\circ} \mathrm{W}$ ), three Snapping Turtle nests in fresh asphalt were observed (Figure 1). The nests were presumed to be about two weeks old, given the normal period of oviposition of Snapping Turtles in Algonquin Provincial Park. The nests were found by S.R.de S. beside a temporary bridge, newly installed as an emergency repair to keep the road open after damage to a culvert from spring runoff. "Cold patch" was used along the sides of the road to stabilize the bridge and reduce erosion from the damaged culvert (B. Steinberg pers. comm. 15 November 2010). Cold patch is a combination of asphalt and stone or gravel, which is mixed with a solvent (e.g., kerosene, diesel, or gasoline of varying composition) to make the asphalt pliable at low temperatures (Speight 2015). The asphalt along the sides of the bridge was not compacted and, thus, was loose to the touch. The smell of petroleum product was obvious. One nest was on the west side and two were on the east side of the bridge, on $45^{\circ}$ slopes within $\sim 60 \mathrm{~cm}$ of the road surface; consequently, there was no risk of tires running over the nests. All three nests had the classic mound and trough characteristics of Snapping Turtle nests (Figure 1) and were easy to 


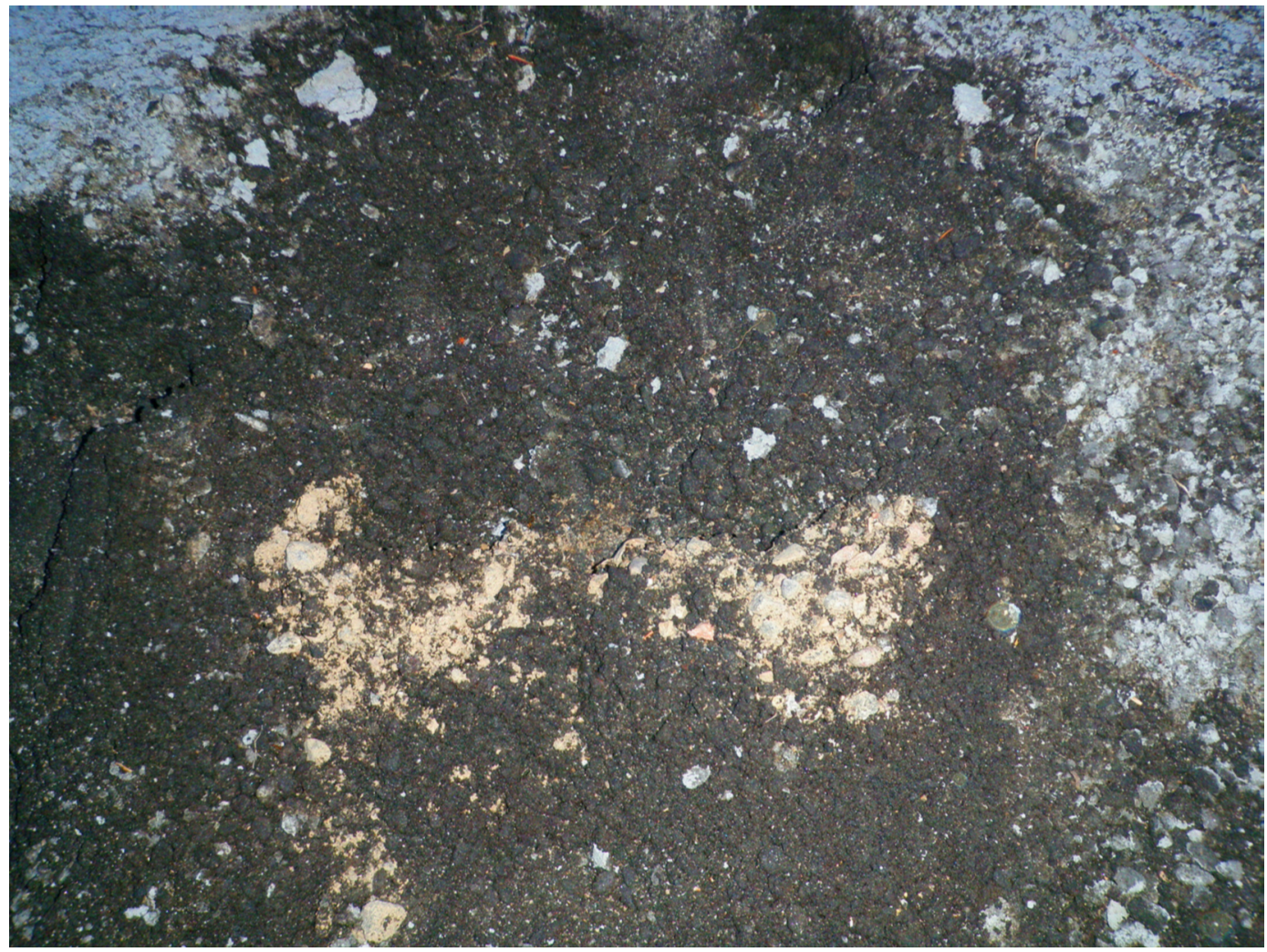

FIGURE 1. Snapping Turtle (Chelydra serpentina) nest deposited in "cold patch" asphalt mixture, beside a bridge in Algonquin Provincial Park, Ontario, 28 June 2009. Photo: Shane de Solla.

spot. This bridge was a known nesting area and Snapping Turtle nests in gravel and sand at this culvert were often depredated in previous years (S.R.de S. pers. obs.).

One nest was excavated immediately, whereas the other two were left untouched. Because the asphalt along the side of the bridge embankment was soft, there was little difficulty digging with a hand shovel. The excavated clutch was beneath the asphalt layer in the sand foundation of the embankment, although a considerable amount of asphalt was mixed with the sand substrate, such that the eggs were directly exposed to asphalt. All excavated eggs displayed black speckled stains (Figure 2), presumably resulting from direct exposure to the asphalt. The asphalt was very sticky and left a thick oily residue on the nitrile gloves used during nest excavation. The excavated eggs were removed from the site, but were unavailable for testing for logistic reasons.

On 28 July 2009, the site was revisited to remove eggs from the two remaining nests for artificial incubation to determine hatching success. One of the nests had been depredated and egg shells were found in the excavated cavity. Furthermore, numerous holes in the asphalt in the general area were observed, consistent with mammalian depredation attempts on turtle nests.
The third clutch was no longer visible, largely because of surficial disturbance by numerous animals, probably Moose (Alces americanus), walking over the bridge embankment. Attempts to find the missing clutch were ceased to minimize further disturbance to the asphalt. Unlike the nest that was excavated just after oviposition on 28 June, the depredated nest cavity was completely within the asphalt with little sand visible and, in the area of the lost nest, the asphalt was deeper than a typical Snapping Turtle nest cavity (i.e., deeper than 10-15 cm; Congdon et al. 2008). Consequently, those eggs would have had greater exposure to asphalt than the previously excavated nest.

Control eggs for an unrelated project from a separate Algonquin site were used to measure PAHs. Five eggs were buried on 28 July in fresh asphalt at a depth of about $12 \mathrm{~cm}$, which is within the typical depth of a Snapping Turtle nest cavity (Congdon et al. 2008). On 5 August, the eggs were removed and sealed in a clear plastic sandwich bag. The eggs that were excavated had obvious staining, substantial black speckling, and an odour of asphalt (Figure 2). Samples of asphalt and sand under the asphalt were also collected and sealed in a plastic bag. They were brought to the Canada Centre 


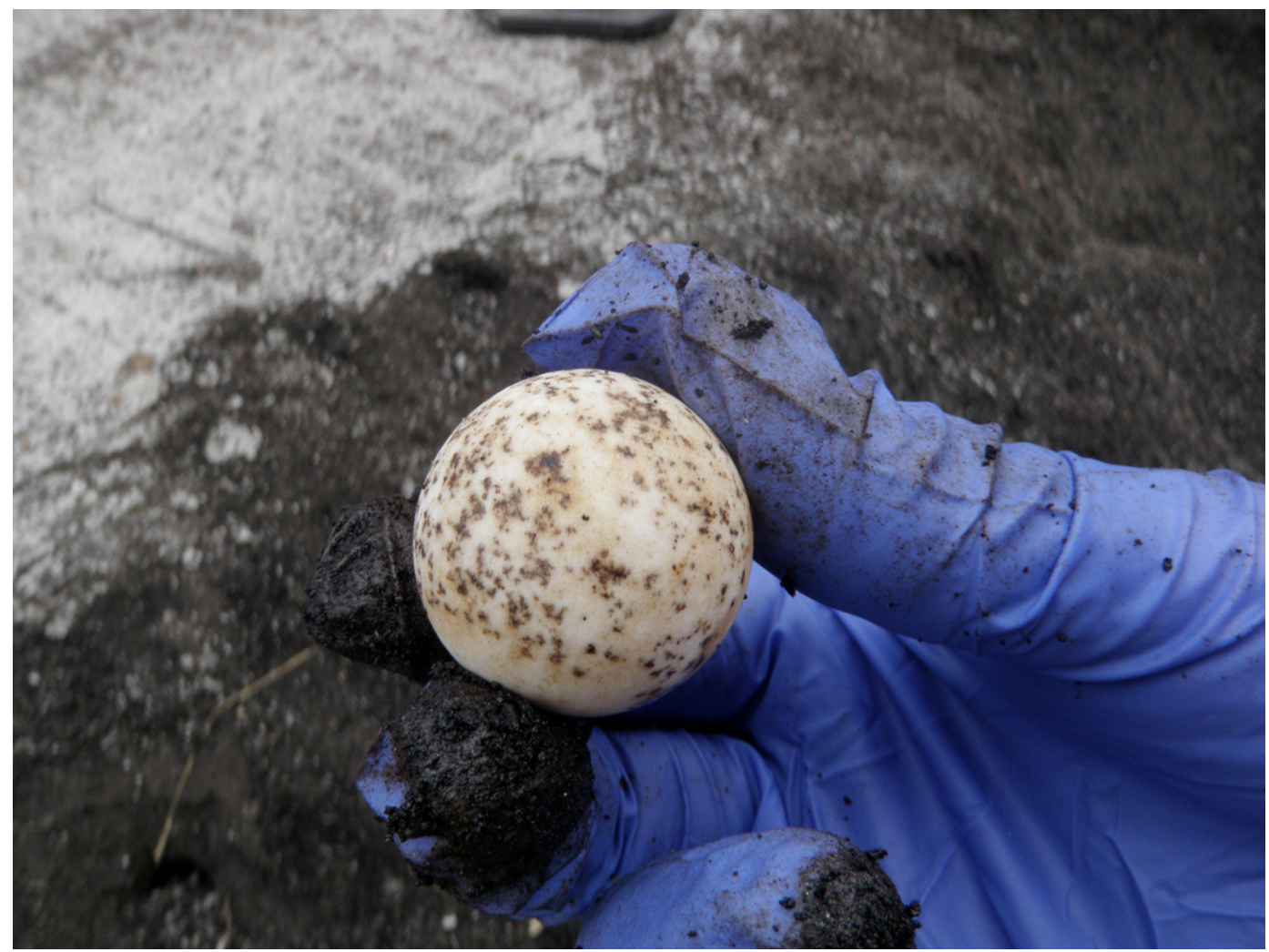

FIGURE 2. Snapping Turtle (Chelydra serpentina) egg showing black stains after eight days incubation in "cold patch" asphalt in Algonquin Provincial Park, Ontario. Photo: Shane de Solla.

for Inland Waters in Burlington the same day and the eggs, asphalt, and soil were placed in a $-80^{\circ} \mathrm{C}$ freezer.

\section{PAH analysis}

The five eggs and soil and asphalt samples were sent to Maxxam Analytical (Mississauga, Ontario, Canada) for measurement of PAH concentrations using gas chromatography in selective ion monitoring mode, based on United States Environmental Protection Agency (EPA) method 8270. Eighteen PAHs (Table 1), including the 16 that are considered priority PAHs by the EPA, were measured in all samples. Reportable detection limits (RDLs) ranged from 0.005 to $0.02 \mu \mathrm{g} / \mathrm{g}$ in turtle eggs and sand and from 0.1 to $0.4 \mu \mathrm{g} / \mathrm{g}$ in asphalt.

\section{Results and Discussion}

The concentrations of six PAHs were found to be above RDLs and that of 1- and 2-methylnaphthalene was highest relative to the other PAHs in the eggs (Table 1). The concentration of all PAHs in eggs ranged from 0.081 to $0.376 \mu \mathrm{g} / \mathrm{g}$ (wet weight). These findings support those of de Solla and Martin (2011) that Snapping Turtle embryos can directly absorb potentially harmful contaminants from material around the nest cavity. The turtles were only exposed to PAHs from the substrate for eight days and, thus, the amount of PAHs absorbed may have been appreciably larger after the full incubation period and may have resulted in more toxicity than what was observed.

Three observations reported here are of note. First, Snapping Turtles will select nesting substrates, including asphalt, where there is some risk of exposure of eggs to toxic chemicals. Second, predators, presumably mammals (e.g., skunks, Raccoons [Procyon lotor], foxes, etc.) are capable of detecting turtle eggs that are buried under a substrate that is pungent to a human nose. Third, turtle eggs may absorb chemicals from asphalt.

We speculate that the asphalt was attractive to the turtles likely because of its high temperature at the time the females were selecting their oviposition site or because of the lack of covering vegetation. At northern latitudes, female Snapping Turtles select exposed locations with relatively warmer substrate temperatures to oviposit than turtles at more equatorial latitudes that select shadier, cooler substrates (Ewert et al. 2005), and they also prefer landscapes with short or little vegetation (Kolbe and Janzen 2002). Soil composition may not be as important in the choice of oviposition site (Hughes and Brooks 2006); Snapping Turtles are known to oviposit in sand, clay, wood chips, beaver lodges and 
TABLE 1. Concentrations of polycyclic aromatic hydrocarbons (PAHs) in Snapping Turtle (Chelydra serpentina) eggs buried in asphalt from 28 July to 5 August 2009 . PAHs in asphalt and in sand immediately below asphalt are also reported.

\begin{tabular}{|c|c|c|c|c|c|c|c|}
\hline \multirow[t]{3}{*}{ Type of PAH } & \multicolumn{7}{|c|}{ Concentration of PAHs, $\mu \mathrm{g} / \mathrm{g}$ wet weight } \\
\hline & \multicolumn{5}{|c|}{ Eggs } & \multirow[b]{2}{*}{ Sand (RDL) } & \multirow[b]{2}{*}{ Asphalt (RDL) } \\
\hline & $\overline{1}$ & 2 & 3 & 4 & 5 & & \\
\hline Acenaphthene & ND & ND & ND & ND & ND & $\mathrm{ND}(0.01)$ & $0.6(0.2)$ \\
\hline Acenaphthylene & ND & ND & ND & ND & ND & ND $(0.005)$ & $\mathrm{ND}(0.1)$ \\
\hline Anthracene & ND & ND & ND & ND & ND & $\mathrm{ND}(0.005)$ & $0.5(0.1)$ \\
\hline Benzo(a)anthracene & ND & ND & ND & ND & ND & $\mathrm{ND}(0.01)$ & $\mathrm{ND}(0.2)$ \\
\hline Benzo(a)pyrene & ND & ND & ND & ND & ND & $\mathrm{ND}(0.005)$ & $0.1(0.1)$ \\
\hline Benzo(b/j)fluoranthene & ND & ND & ND & ND & ND & $\mathrm{ND}(0.01)$ & $\mathrm{ND}(0.2)$ \\
\hline Benzo(g,h,i)perylene & ND & ND & ND & ND & ND & ND $(0.02)$ & $0.5(0.4)$ \\
\hline Benzo(k)fluoranthene & ND & ND & ND & ND & ND & $\mathrm{ND}(0.01)$ & $\mathrm{ND}(0.2)$ \\
\hline Chrysene & ND & ND & ND & ND & ND & $\mathrm{ND}(0.01)$ & $\mathrm{ND}(0.2)$ \\
\hline Dibenz(a,h)anthracene & ND & ND & ND & ND & ND & ND $(0.02)$ & $\mathrm{ND}(0.4)$ \\
\hline Fluoranthene & ND & ND & ND & ND & ND & $0.006(0.005)$ & $0.2(0.1)$ \\
\hline Fluorene & 0.007 & 0.008 & 0.006 & ND & ND & ND $(0.005)$ & $1.5(0.1)$ \\
\hline Indeno(1,2,3-cd)pyrene & ND & ND & ND & ND & ND & $\mathrm{ND}(0.02)$ & $\mathrm{ND}(0.4)$ \\
\hline 1-methylnaphthalene & 0.110 & 0.130 & 0.081 & 0.034 & 0.037 & $-(0.005)$ & - \\
\hline 2-methylnaphthalene & 0.140 & 0.170 & 0.097 & 0.037 & 0.044 & $-(0.005)$ & - \\
\hline Naphthalene & 0.051 & 0.061 & 0.036 & 0.010 & 0.020 & ND (0.005) & $1.5(0.1)$ \\
\hline Phenanthrene & 0.006 & 0.007 & 0.005 & ND & ND & ND $(0.005)$ & $3.2(0.1)$ \\
\hline Pyrene & ND & ND & ND & ND & ND & $0.009(0.005)$ & $0.7(0.1)$ \\
\hline
\end{tabular}

Note: $-=$ no data, $\mathrm{ND}=$ not detected, RDL $=$ reportable detection limit.

dams, gravel, vegetable gardens, grass fields, and other substrates (Robinson and Bider 1988; de Solla et al. 2001; Congdon et al. 2008).

Road and habitat types may influence predation patterns. Although some believe that mammalian predators find turtle nests primarily through visual cues (e.g., Strickland et al. 2010), they are more generally assumed to use olfactory cues (Spencer 2002; Burke et al. 2005). Regardless of the mechanism(s) predators use, it is evident from our observations that they are capable of finding turtle nests in substrates containing chemicals that can interfere with olfactory senses and substrates with non-typical physical structure that can interfere with visual senses. Predators may even prefer unnatural habitats, such as roadsides, for hunting (Mata et al. 2017).

Snapping Turtles can spend substantial time selecting oviposition sites and appear to select substrate and environmental conditions that are suitable for egg development, but they clearly sometimes select substrates or conditions that may result in exposure to contaminants or other stressors. For example, female Snapping Turtles have been observed laying eggs in compost that was sufficiently hot to kill both the eggs and nesting turtles (de Solla et al. 2001). Reptiles sometimes oviposit in agricultural fields (Rauschenberger et al. 2004; de Solla and Martin 2007), in substrates that have been exposed to oil (Van Meter et al. 2006), or coal-ashcontaminated soils (Nagle et al. 2001).

Although Snapping Turtle eggs from a site contaminated with heavy metals and PAHs had lower hatching success and increased deformities relative to controls (Bell et al. 2006), the effect of PAHs and oil on turtle egg development is less clear. Exposure to both oil and PAHs (through topical application to the eggshell) increased deformity rates in turtle eggs from Algonquin Provincial Park (Van Meter et al. 2006). Although turtle eggs are capable of absorbing PAHs from soil contaminated with Arabian light crude oil (after exposure of up to $1 \mathrm{~L}$ of $10 \mathrm{~g}$ oil/L water in soil, eggs contained up to $0.56 \mu \mathrm{g} / \mathrm{g}$ of total PAHs), PAH exposure did not affect either hatching success or deformity rate (Rowe et al. 2009). Incidents of oviposition in asphalt as described here are presumably not common, but turtles frequently use roadsides for oviposition.

Reptiles may be exposed to PAHs through avenues other than contaminated soil. Studies have discovered the presence of PAHs in wild reptiles, but there are few studies that illustrate how PAHs affect health and development. PAHs were found in wild Loggerhead Sea Turtle (Caretta caretta) plasma samples and correlated with electrolyte levels as well as blood enzymes (Camacho et al. 2013). In addition, total proteins, albumin, globulins, and creatinine were positively correlated with PAHs. The authors suggested that these correlations could reflect altered kidney function. In a separate study, significant levels of PAHs were found in various tissues, predominantly in skin and kidney samples of two species of sea snakes (Sereshk and Bakhtiari 2014). Partial life cycle PAH exposure studies would be beneficial in determining deleterious effects in reptiles.

\section{Acknowledgements}

We thank Ontario Ministry of Natural Resources and Forestry (OMNRF) staff at Algonquin Provincial Park for permission to collect Snapping Turtle eggs, Brad 
Steinberg (OMNRF, Algonquin Provincial Park, Ontario) for his comments on the repaired bridge, the Ontario Turtle Action Group for their interest, Doug Crump for not injecting all the eggs on 28 July, and Pam Martin and Kimberley McCormack for their contribution to an unrelated project on PAH absorption in turtle eggs. Funding was provided by Environment and Climate Change Canada. Kyna Intini provided valuable comments on the manuscript.

\section{Literature Cited}

Aresco, M.J. 2005. The effect of sex-specific terrestrial movements and roads on the sex ratio of freshwater turtles. Biological Conservation 123: 37-44.

Bell, B., J.R. Spotila, and J.D. Congdon. 2006. High incidence of deformity in aquatic turtles in John Heinz National Wildlife Refuge. Environmental Pollution: 142: 457-465. https://doi.org/10.1016/j.envpol.2005.10.020

Burke, R.L., C.M. Schneider, and M.T. Dolinger. 2005. Cues used by raccoons to find turtle nests: effects of flags, human scent, and Diamond-backed Terrapin sign. Journal of Herpetology 39: 312-315. https://doi.org/10.1670/199$03 \mathrm{~N}$

Camacho, M., L.B. Octavio, L.D. Boada, L.F.L. Jurado, M. Medina, M. Zumbado, and J. Orós. 2013. Potential adverse health effects of persistent organic pollutants on sea turtles: evidences from a cross-sectional study on Cape Verde loggerhead sea turtles. Science of the Total Environment 458-460: 283-289. https://doi.org/10.1016/j.scitote nv.2013.04.043

Congdon, J.D., J.L. Greene, and R.J. Brooks. 2008. Reproductive and nesting ecology of female Snapping Turtles. Pages 123-134 in The Biology of the Snapping Turtle. Edited by A.C. Steyermark, M.S. Finkler, and R.J. Brooks. Johns Hopkins University Press, Baltimore, Maryland, USA.

de Solla, S.R., D.G. Campbell, and C.A. Bishop. 2001. Hyperthermia induced mortality of gravid Snapping Turtles, Chelydra serpentina, and eggs in a wood chip pile. Canadian Field-Naturalist 115: 510-512. Accessed 27 October 2018. https://biodiversitylibrary.org/page/35014 673.

de Solla, S.R., and K.J. Fernie. 2004. Is cost of locomotion the reason for prolonged nesting forays of Snapping Turtles (Chelydra serpentina)? Canadian Field-Naturalist 118: 610-612. https://doi.org/10.22621/cfn.v118i4.67

de Solla, S.R., and P.A. Martin. 2007. Toxicity of nitrogenous fertilizers to eggs of Snapping Turtles (Chelydra serpentina) in field and laboratory exposures. Environmental Toxicology and Chemistry 26: 1890-1895. https://doi.org/ 10.1897/06-500R1.1

de Solla, S.R., and P.A. Martin. 2011. Absorption of current use pesticides by snapping turtle (Chelydra serpentina) eggs in treated soil. Chemosphere 85: 820-825. https:// doi.org/10.1016/j.chemosphere.2011.06.080

Ewert, M.A., J.W. Lang, and C.E. Nelson. 2005. Geographic variation in the pattern of temperature-dependent sex determination in the American Snapping Turtle (Chelydra serpentina). Journal of Zoology 265: 81-95. https://doi. org/10.1017/S0952836904006120

Hughes, E., and R.J. Brooks. 2006. The good mother: does nest site selection constitute parental investment in turtles? Canadian Journal of Zoology 84: 1545-1554. https://doi. org/10.1139/z06-148
Kolbe, J.J., and F.J. Janzen. 2002. Spatial and temporal dynamics of turtle nest predation: edge effects. Oikos 99: 538-544. https://doi.org/10.1034/j.1600-0706.2002.11853.x

Loncke, D.J., and M.E. Obbard. 1977. Tag success, dimensions, clutch size and nesting site fidelity for the Snapping Turtle, Chelydra serpentina, (Reptilia, Testudines, Chelydridae) in Algonquin Park, Ontario, Canada. Journal of Herpetology 11: 243-244. https://doi.org/10.2307/1563158

Mata, C., P. Ruiz-Capillas, and J.E. Malo. 2017. Small-scale alterations in carnivore activity patterns close to motorways. European Journal of Wildlife Research 63: 64. https:// doi.org/10.1007/s10344-017-1118-1

Nagle, R.D., C.L. Rowe, and J.D. Congdon. 2001. Accumulation and selective maternal transfer of contaminants in the turtle Trachemys scripta associated with coal ash deposition. Archives of Environmental Contamination and Toxicology 40: 531-536. https://doi.org/10.1007/s00244 0010206

Obbard, M.E., and R.J. Brooks. 1980. Nesting migrations of the Snapping Turtle (Chelydra serpentina). Herpetologica 36: 158-162.

Rauschenberger, R.H, J.J. Wiebe, M.S. Sepulveda, J.E. Buckland, and T.S. Gross. 2004. Predicting maternal body burdens of organo-chlorine pesticides from eggs and evidence of maternal transfer in Alligator mississippiensis. Environmental Toxicology and Chemistry 23: 2906-2915. https://doi.org/10.1897/03-584.1

Robinson, C., and J.R. Bider. 1988. Nesting synchrony - a strategy to decrease predation of snapping turtle (Chelydra serpentina) nests. Journal of Herpetology 22: 470-473. https://doi.org/10.2307/1564342

Rowe, C.L., C.L. Mitchelmore, and J.E. Baker. 2009. Lack of biological effects of water accommodated fractions of chemically- and physically-dispersed oil on molecular, physiological, and behavioral traits of juvenile Snapping Turtles following embryonic exposure. Science of the Total Environment 407: 5344-5355. https://doi.org/10.1016/j. scitotenv.2009.06.036

Sereshk, Z.H., and A.R. Bakhtiari. 2014. Distribution patterns of PAHs in different tissues of annulated sea snake (Hydrophis cyanocinctus) and short sea snake (Lapemis curtus) from the Hara Protected Area on the North Coast of the Persian Gulf, Iran. Ecotoxicology and Environmental Safety 109: 116-123. https://doi.org/10.1016/j.ecoenv.20 14.06.004

Speight, J.G. 2016. Nomenclature and terminology. Pages 3-43 in Asphalt Materials Science and Technology. Butterworth-Heinemann, Oxford, United Kingdom. https:// doi.org/10.1016/C2013-0-15469-4

Spencer, R.J. 2002. Experimentally testing nest site selection: fitness trade-offs and predation risk in turtles. Ecology 83: 2136-2144. https://doi.org/10.1890/0012-9658(2002)083 [2136:ETNSSF]2.0.CO;2

Strickland, J., P. Colbert, and F.J. Janzen. 2010. Experimental analysis of effects of markers and habitat structure on predation of turtle nests. Journal of Herpetology 44: 467-470. https://doi.org/10.1670/08-323.1

Van Meter, R.J., J.R. Spotila, and H.W. Avery. 2006. Polycyclic aromatic hydrocarbons affect survival and development of common Snapping Turtle (Chelydra serpentina) embryos and hatchlings. Environmental Pollution 142: 466-475. https://doi.org/10.1016/j.envpol.2005.10.018

Received 26 January 2018

Accepted 26 June 2018 